\title{
The Intermarium in Ukrainian and Polish Foreign Policy Discourse
}

\author{
Oleksii Polegkyi \\ Canadian Institute of Ukrainian Studies, University of Alberta
}

\begin{abstract}
The ongoing Russian-Ukrainian conflict, crises in the European Union (EU), and armed conflicts in the EU neighbourhood have influenced the prospects of future development in eastern and central Europe. A search for new security architecture on the margins of the EU and regional collaborations that prevail across formal EU borders have forced national elites in Poland and Ukraine to redefine their efforts regarding regional and security co-operation. Rationales for joining an Intermarium (a regional, transnational project involving successor states of the former PolishLithuanian Commonwealth countries) are based on the perception of a threat coming from Russia. This article analyzes the Intermarium concept, first, from the perspective of "geopolitical imaginary" with emphasis on periphery-centre relations and, second, in the light of regional "security dilemma" as it appears in attempt of "smaller" states to counteract Russian threats.
\end{abstract}

Keywords: Intermarium, geopolitics, discourse, Poland, Ukraine.

\section{INTRODUCTION}

T he countries between the Baltic and the Black seas have geopolitical and historical battlegrounds in which western and eastern "great" powers have vied for continental dominance. Western scholars usually view this area as a peripheral space, a borderland between civilizations. The central question for the European Union's eastern policy is how to create a zone of peace and stability at its borders without offering the prospect of full membership for such countries as Ukraine. For some countries in central and eastern Europe, the task is to avoid falling into the status of "buffer" state or, at least, to limit the negative consequences of such a fall.

Each country defines and constructs a geopolitical space based on the geopolitical imagination of its political elite. The Russia's conduct in the postSoviet space has deeply influenced the way in which the geopolitical imagination of Polish and Ukrainian leaders has evolved. Russia, the European Union (EU), and the United States are major stakeholders in the "power" politics that characterize eastern Europe. Russia and the EU have radically different approaches to the mechanisms and institutions of region building. Russia prefers the concept of the "near abroad" to the "common 
neighbourhood" and overwhelmingly perceives this area in terms of a zerosum game and spheres of influence politics.

The Russian-Ukrainian war that began in 2014, and is ongoing at this writing, changed the geopolitical situation in the region. Ukraine presently faces a considerable security challenge and has a great opportunity to rethink established security concepts and to examine prospects for regional co-operation in central and eastern Europe (Polegkyi).

Russia's annexation of Crimea and the ongoing war in the Donbas require Ukrainian leaders to search for new security architecture that can guarantee stability. Under these conditions, Ukraine has found it necessary to build new relations with key international actors and to establish an appropriate environment on its border. The rationalization of the Intermarium as a regional transnational co-operation project is nowadays mainly based on the perception of a threat coming from Russia. The crucial role attributed to Poland and Ukraine in this project is based on their unique historical experience in balancing this threat.

This paper examines how the ideas of regional co-operation and the Intermarium conceptualized in the Polish and Ukrainian political discourses and considers their political and practical potential. The historical roots of the Intermarium concept are examined with respect to its geopolitical and political implications and its place in modern-day politics.

\section{THEORETICAL BACKGROUND}

According to traditional geopolitical approach, competitions for power are to some extent influenced by a state's geographical location, and geopolitical visions are often inherited from historical, ideological, and discursive representations of the space. This approach utilizes such concepts as competition over spheres of influence, space-power relations, core and periphery-which are important for the depiction of the traditional representation of the "Intermarium" concept.

The critical geopolitics seeks to explain the practices by which political actors construct and spatialize international politics. "Geopolitical imaginary" developed by Gearóid O'Tuathail, is a set of common representations of power relations and geography that may affect policy decisions and popular perceptions of the world order. According to O'Tuathail, geopolitics is "not a concept that is immanently meaningful and fully present to itself but a discursive 'event' that poses questions to us whenever it is evoked and rhetorically deployed" (17). We can say that it is not security issues in themselves that are important, but rather issues that have been "securitized," that is, discursively constructed as a threat. 
The security dilemma model is an appropriate conceptual approach to assess the redefinition of security and foreign policy of central and eastern European (CEE) states and their reactions to security threats from Russia (Jervis; Buzan and Waever; Waltz). According to the defensive realism approach, the security dilemma referred to in the model above appears as a spiral of insecurity. The security dilemma describes a situation in which one state's efforts to strengthen its security is perceived as a threat to the security of other states and counteractions to this threat may be taken, for instance, by instituting a balance of power using allies and alliances. Thus, the Intermarium, an alliance of smaller states facing strategic threats from an expansionist state-Russia-is a typical defensive response. The relative peace and the secure position of Poland in the post-Cold War period are now threatened by the growing ambitions of the Russian Federation. At the same time, Poland is an emerging leader within central Europe, reflecting the growing ambitions of Polish leaders.

The geopolitical context of periphery/margins-centre/core relations display itself within the available discourses, and influences power-state relations as well as identities, strategies, and finally political actions of actors. The relationship and interdependence of periphery and centres can be used to understand the natures, roles, meanings, and their mutual impacts. Periphery-centre positioning is always given to actors, but it is changeable and depends on context and discursive arrangements. No periphery can be determined without one or more centres, and vice versa. In the Polish geopolitical imaginary in the relation to Ukraine or other former Soviet countries, Poland is a core. However, in relations with the European "core," Poland is often marginalized to the periphery of "old" Europe.

\section{INTERMARIUM: A CONCEPTUAL BACKGROUND}

The term "Intermarium" signifies "land between the seas" (Międzymorze, in Polish) and is used to refer to the alliance of states between the Baltic Sea and the Black Sea, and in some cases the Adriatic Sea. This area has been highly contested in the past, leading to dramatic changes in borderlines. The idea of the Intermarium predicates a deep co-operation, or even a confederation, of the states situated between the Baltic and Black seas faced with threats from Russia (Umland; Balcer); it has been studied by many Polish scholars (for example, Maszkiewicz; Chodakiewicz; Gajowniczek; Szczepański; Olbrycht).

The idea of the Intermarium, first proposed by Adam Jerzy Czartoryski in the nineteenth century, was reformulated as a political concept by the Polish political leader Józef Piłsudski after World War I. Piłsudski aimed to 
establish an anti-Communist federation of countries in eastern Europe that were united by their common opposition toward Soviet Russia. When Poland got its independence, Piłsudski proposed a federation of eastern European states that could be strong enough to counterbalance Germany and a rising Soviet Union. Later, Piłsudski broadened this concept to an "Eastern European League of Nations," wherein Poland and Lithuania could form a federal state in the east (including Belarus with special autonomy). Ukraine and Romania could enter into military and political confederacy with Poland, Finland and the Baltic states would comprise a "Baltic Bloc," and Caucasus countries could create a "Federal State of Caucasia." These optimistic plans to build an eastern European federation under Polish leadership did not come to fruition (Laruelle and Rivera).

Another geopolitical approach suggested by Piłsudski was the establishment of a Promethean League. Its main goal was to provoke ethnic minorities integrated into the Soviet Union after the Bolshevik revolution of 1917 to fight for independence within the USSR. The Promethean League would theoretically activate the disintegration of the Soviet Union into individual states, and Poland could play a leading role in a broad federation of eastern European states (Maszkiewicz). However, by 1921 Ukraine was fighting for its independence; the Treaty of Riga divided Ukraine, Belarus, and Lithuania between Poland and Bolshevik Russia; and the borders being redrawn in this part of Europe served as a core cause of future conflicts.

A more serious attempt to apply the Intermarium concept to practical politics is associated with Józef Beck, Poland's interwar foreign minister (1932-39). Beck perceived that collaboration within central-eastern European countries could guarantee the survival of Poland in the face of growing powers in Germany and the USSR. The pragmatism of Beck's political approach was based on geopolitical realities and security issues rather than ideological concepts. Beck believed it was necessary for Poland to enter into alliances with small and medium-sized states situated between the Baltic, Adriatic, and Black seas. However, this approach was never fully implemented (Ištok et al.).

In the first part of the twentieth century, Ukrainian intellectuals and politicians, such as Mykhailo Hrushevs'kyi, Stepan Rudnyts'kyi, and Iurii Lypa, tried to develop different concepts of regional co-operation for Ukraine, for instance, a "Black Sea orientation." Rudnyts'kyi theorized that the creation of a Baltic-Black Sea Federation would give Ukraine open access to central Asia, giving it key player status in the Eurasian system of communication. Hrushevs'kyi noted that a Black Sea orientation would enable Ukraine to co-operate with Black Sea nations, and possibly to participate in the restoration of old natural trade routes. Lypa supposed that the establishment of a "Black Sea fortress" in co-operation with the Caucasus and the "Iranian platform" would secure Ukraine's position and open an 
Atlantic-Indian ocean route. Hrushevs'kyi's argumentation was historical, Rudnyts'kyi's was political and geographical, and Lypa's was geopolitical.

Even after World War II, Polish emigrants kept the ideas of Intermarium and Prometheism alive. A group of Polish intellectuals associated with the Parisian journal Kultura and headed by Jerzy Giedroyć (1906-2000) and Juliusz Mieroszewski (1906-76) contributed to the development of the socalled ULB (Ukraine-Lithuania-Belarus) geopolitical project as a potential approach to Polish foreign policy, following a weakening in the Soviet control of eastern Europe. They believed that Poland's first priority in its eastern strategy should be to support the independence of its eastern neighbours, particularly Ukraine, Belarus, and Lithuania, because an independent Poland is possible only if Ukraine, Belarus, and Lithuania keep their independence. As with Piłsudski's Intermarium project, the ULB concept was based on the liberation of central-eastern European nations from Soviet rule in close collaboration with the Polish nation (Ištok et al. 15).

In the vision of some Polish thinkers, the borders of this Intermarium did not always coincide with geographic boundaries, or at least such coincidence was not the most important factor (Szczepański). This Intermarium was based on cultural and civilizational specifics, as well as on the historically shaped identity of the countries of the Polish-Lithuanian commonwealth situated between the Baltic, Adriatic, and Black seas, which geographically overlapped the territory of central and eastern Europe (Olszański). This "Slavic space," shaped by a common culture, was based on several historical resentments: fear of the hegemony of Germany, tensions with Islamic Turkey, and Russian imperialism.

Following the collapse of Soviet Union in 1991, there was a renewed focus on the Intermarium concept in Polish geopolitical thinking. Warsaw's foreign policy is still influenced by the belief that the independence of Ukraine and of Belarus is a precondition for the survival and security of Poland. "The efforts of the Polish president L. Walęsa to forge a strategic partnership with Ukraine at the beginning of the 1990s can be considered as an example of Polish foreign policy implemented in accordance with the Jagiellonian understanding of the Intermarium" (Ištok et al. 317).

Before Poland's accession to the EU, some Polish politicians argued that a "new" Intermarium project might be useful in the context of European integration (Moczulski). According to this vision a deep collaboration between the central-eastern European states would benefit all the small states in this area and reinforce their positions within the European Union. Poland would represent the smaller states during the negotiations regarding EU accession.

An Intermarium idea was promoted recently by Polish presidents Lech Kaczynski and Andrzej Duda. In his inauguration address in August 2015, newly elected President Duda announced that the creation of an alliance 
among the states between the Baltic, Black, and Adriatic seas would be at the core of his foreign policy. Duda mentioned two crucial aspects related to the Intermarium concept in November 2015: (1) the Intermarium might help central and eastern European countries to speak in a common voice, and (2) Poland will lobby for the enlargement of NATO bases in the region (Szelachowska). Later, Duda's rhetoric regarding Intermarium co-operation was replaced more and more by the idea of a "Three Seas Initiative" (TSI). The Three Seas strategy, therefore, is presented by Polish leadership as a correction to Poland's foreign policy, rather than a revolutionary change.

UKRAINE: EUROPEAN ASPIRATIONS AND THE SEARCH FOR A NEW SECURITy ARCHITECTURE

Before the Euromaidan Revolution of 2013-14, Ukraine tried to balance its position between Russia and Europe to match its geographical position and its regional and social diversity. For Ukraine, "returning to Europe" implies the rejection of Russian domination. Many Ukrainians thought that forging closer ties with Europe and the United States would offer Ukraine some protection against an unpredictable Russia. The perception of Ukraine as being European geographically but not European politically and culturally is deep-rooted in Europe. Ukraine is viewed as a liminal category between east and west, from the perspective of Russia and Europe as two opposite poles.

Ukraine's domestic and foreign policies are oriented toward the European Union (EU), and Ukraine is politically sensitive to its treatment by the EU. Kataryna Wolczuk emphasizes that although the EU wanted to be instrumental in mobilizing support for reform-oriented forces in Ukraine, the process of rapprochement has become "political" on both sides. The EU tends to answer Ukraine's political demands with bureaucratic and technical responses.

After the Euromaidan Revolution, Euro-Atlantic integration became an option for Ukraine. Ukrainian elites, as well as the majority of the population, proclaim their willingness to connect with Europe, and EU integration has been advanced by almost all large political parties as a matter of national security. A nationwide opinion poll carried out in August 2018 cited 52\% in favour of becoming an EU member, 34\% opposed to becoming an EU member, and $15 \%$ as undecided. These data were similar to data collected by other research institutions after 2014 (Fond "Demokratychni initsiatyvy" im. Il'ka Kucheriva; Sotsiolohichna hrupa "Reitynh"; Kyiv International Institute of Sociology). However, Ukraine has not received a clear signal from the EU about the prospects of EU membership. The Euromaidan Revolution was a challenge for European foreign policy because of the absence of a clear vision of the Ukrainian future. The domestic political struggle and the failure 
to implement a comprehensive reform strategy have reduced Ukraine's chances to be accepted as an EU member.

Officially launched in 2004, the EU's European Neighbourhood Policy (ENP) was an attempt to create a zone of peace and stability at the EU's external borders, and to avoid the emergence of new dividing lines between the EU and neighbouring countries that are somewhat integrated but are not formally part of the EU. The ENP was explicitly designed to provide an alternative to EU membership and has therefore been criticized by Ukraine. The ENP offers Ukraine aid in exchange for political and economic reforms, but nothing more (Popescu and Wilson). Therefore, Ukraine must find its own way to effectively defend its national interests (Horbulin et al.).

The relationship with Russia has always been one of the most complicated problems confronting Ukraine's foreign policy. Since the collapse of the USSR, Russian policy-makers have been driven to reconstitute Russia as a "great power." The Russian imperial position on Ukraine is clear: Russia has its own sphere of influence and Ukraine is a part of it. Changes in Russian foreign policy became evident in 2005 after the Ukrainian Orange Revolution. The Orange Revolution was regarded by Russian elites as the result of western influence and awakened fears in the Kremlin that the Ukrainian experience might serve as a model for attempted political change in Russia itself (Tsygankov). In Russian perceptions, the European Union has always been about geopolitics, focused on creating a competitive universal project that spreads beyond the EU borders. Russia's first attempt to "check" the ability and willingness of the west to counteract Russian aggressive revanchism was the war in Georgia in 2008.

Vladimir Putin radically shifted Russia's political course in 2012 after a series of protests by Russia's political opposition. The Kremlin began to develop a rival "counterrevolutionary" ideology (Popescu and Wilson). The reality of a new "colour" revolution in its borders was one of the main fears of the Kremlin. The Euromaidan Revolution in Ukraine was perceived by the Kremlin as another "special operation" of the west directed against Russia.

Due to increasing domestic threats to his rule, in his third term Putin turned to foreign policy to mobilize the population and legitimize his leadership (Laruelle). Eurasianism in recent years has been adopted by the Kremlin as an official ideology that puts Russia at the centre of a unique Eurasian culture despite its weak realization in practical terms (White and Feklyunina).

Russian political elites prefer to see the former Soviet countries as buffer states under Russian influence, which gives Russia a certain "moral right" and even obligation to interfere in the internal issues of neighbouring countries. For instance, after occupying Crimea, in his famous speech on 18 March 2014, President Putin justified the annexation citing historical and moral reasons for Russia's actions: 
In people's hearts and minds, Crimea has always been an inseparable part of Russia. The residents of Crimea and Sevastopol turned to Russia for help in defending their rights and lives." Referring to the fact that millions of Russians and Russian-speaking people live in Ukraine, he declared: "Russia will always defend their interests using political, diplomatic, and legal means. (Address by the President of the Russian Federation)

Andrey Makarychev identifies four main tenets of Russia's geopolitical neighbourhood policy: (1) explicitly anti-neoliberal, which makes the policy especially popular among both conservatives and the left; (2) a common denominator of perceived fluidity of Russian borders as movable frontiers; (3) a high price for European identification (that entails Russia's submission to Europe); and (4) military confrontation as the only alternative to a Russian sphere of influence throughout the post-Soviet space (15).

The Ukrainian experts Borys Parakhons'kyi and Halyna Iavors'ka posit that under the new geopolitical conditions, taking into account regional processes and the interests of European countries, it is evident that the Black Sea security system should provide a strong counteraction to the imperial ambitions of the Russian Federation (27). Such counteraction requires the creation of a flexible alliance and the permanent co-operation of democratic states. Russian military aggression has created a unique opportunity to update regional partnerships in the military sphere. Indeed, as Volodymyr Horbulin and others confirm:

If we talk about a broader format, it would be also beneficial to create an informal association with the participation of Ukraine and its responsible partners-Baltic countries, Sweden, Poland, Slovakia, the Czech Republic, Romania-like the Little Entente after World War I-as an example of countries of the region having different development but common threats, a co-ordinated policy to deter external aggression and enhance mutual security .... (Horbulin et al. 27)

According to its 2015 National Security Strategy, Ukraine views the Black Sea region, along with Central and Eastern Europe, as zones of its priority interests ("Pro rishennia"). Ukraine takes part in the Black Sea Economic Cooperation (BSEC) organization and in initiatives that promote peace and stability in the Black Sea basin-the Black Sea Naval Force (BLACKSEAFOR) and in the framework of the "Document on Confidenceand Security-Building Measures in the Black Sea Area." Hennadiy Maksak and others argue, however, that at the same time, Ukraine's foreign policy lacks pro-active character, narrowly concentrating on internal security problems. Therefore, Ukraine cannot participate in many regional forms of co-operation (Maksak et al.). 


\section{POLISH Foreign Policy: The Rise of Ambitions}

For centuries, Polish foreign policy was determined by the geopolitical position of Poland between Germany and Russia. Since Poland joined the EU, it has been redefining its role in Europe, particularly in the central and eastern European region (Lada). According to Polish Foreign Policy Strategy 2017-21, Poland's "geographical location poses many challenges, but also offers unique opportunities to strengthen Poland's international position" (4). Currently, Poland perceives the European Union and NATO as guarantors of its stability and independence: "The North Atlantic Alliance continues to serve as the bedrock of Polish and European security. Poland's strategic goal is to ensure that NATO maintains its central role as the guarantor of security in Europe" (Polish Foreign Policy Strategy 2017-21 7).

Debates regarding Poland's future development and the possibilities for regional collaborations that overlook formal EU borders have pushed Polish leaders to look for redefinitions of its regional and security collaborations (Starzyk and Tomaszewska). While European integration has until now been the main source of engagement with EU neighbours, today the attractiveness of the EU has diminished. Poland seeks to increase its role as a regional player, while at the same time it faces broader external challenges, primarily linked with Russian ambitions in the region: "Poland's security environment has deteriorated considerably as a result of Russia's annexation of Crimea and the Russian-provoked conflict in eastern Ukraine" (Polish Foreign Policy Strategy 2017-20214).

Poland's ambition to rank among the main voices of the EU has been visible since its accession in 2004, and for the last several years, Poland has shown an increasing desire to be among the main European players based on its relative domestic stability and Europe's instability (Wagrowska 32). Contrary to many other countries in the region (except, maybe, Hungary), Poland is struggling to achieve the status of "middle" or "regional" power, claiming independence in its internal politics. Jakub Potulski argues that because of its political potential, Poland should be "(1) a regional leader that plays a dominant role in Central and Eastern Europe; (2) and because of its historical experience should implement Europe's eastern policy; (3) will be an advocate and mentor to countries such as Belarus and Ukraine, which after the collapse of the Soviet Union remained outside the European Union" (184).

The three main concepts of Polish foreign policy in the eastern neighbourhoods are political realism, political romanticism, and political pragmatism (Dudek). However, Intermarium as working and realistic concept was not seriously appropriated by any Polish governments in postcommunist Poland. The Ukraine-Belarus-Lithuania idea was and still is the dominant conceptualization of Polish security interests in the light of threat 
coming from Russia (Atlanticism is the other). These three concepts of Polish foreign policy are discussed below.

\section{The Concept of Political Realism in Polish Politics}

According to political realism, all nations are guided by selfishness. The realist discourse is linked to interwar right-wing nationalists associated with the political party "National Democracy," headed by Roman Dmowski. Dmowski (1864-1939) was the main opponent of the Intermarium concept in Polish interwar politics. Today, some right-wing nationalistic politicians (e.g., Janusz Korwin-Mikke and Paweł Kukiz) represent this approach. They think Polish security should be based on constructive relations between Russia and Poland, and treat Ukraine and Belarus as impermanent states, incapable of independent existence. This approach proposes that Polish foreign policy should be defined based on economic criteria: Poland needs to secure access to cheap energy resources as well as markets for Polish goods-both best provided by Russia. These Polish politicians suggest that Poland should maintain good relations with Russia and avoid engaging in disputes that do not concern Poland or do not directly relate to Poland's economic interests.

\section{The Jagiellonian Alternative: Romanticism in Polish Politics}

This approach creates an ideological base for an Intermarium project. According to the "Jagiellonian paradigm," the nation is a cultural community rooted in history. Followers of this approach believe that the nation-states can form alliances but consider national differences to be a value. The concept refers to the time of the Jagiellonian dynasty that ruled in Poland and Lithuania (including lands of Belarus and Ukraine) between the fourteenth and sixteenth centuries. Poland here is conceptualized as a regional power responsible for the situation in the territories of modern Ukraine, Belarus, and Lithuania.

\section{Pragmatism in Polish Politics}

Polish political pragmatism lies in the rejection of the dream of "Poland from sea to sea." Poland is a medium-sized country that conducts foreign policy in coordination with and through institutions of the European Union. As a part of Europe, Poland is guaranteed prosperity and national security. To achieve 
common objectives, it is necessary to further integrate and centralize the power of the European Union, while preserving ethnic and cultural diversity. The Polish role in Europe is to mediate relations with the countries of eastern Europe, not excluding possible co-operation with Russia. Poland should support Ukraine, not in order to create a Polish-Ukrainian alliance but as a promoter of Ukraine in EU structures.

The diplomatic focus of the political party Civic Platform that came to power in Poland in 2007 was directed toward improving Poland's relations with Russia. However, policy-making in the Civic Platform's administration in 2008-15 was strongly pro-European; consequently, Intermarium ideas weakened in that period, even though Poland was among the initiators of the Eastern Partnership, a project intended to strengthen the EU's ties with its eastern neighbours (Bieńczyk-Missala). The administration of the political party Law and Justice became more euro-sceptical, especially after 2015, and started limited initiatives in relations with Russia. For instance, the Polish foreign minister Witold Waszczykowski directly mentioned the divergence of EU and Polish visions: "Europe-weakened by recession, split over different visions of development of the European project, and beset by wars waged at its doorstep-has been pulled into the centre of this global uncertainty and instability" (Polish Ministry of Foreign Affairs).

Another regional initiative that Poland emphasizes in its foreign policy is the Visegrad Group (V4) (Czech Republic, Hungary, Poland, Slovakia). The four states have common interests in areas such as migration policy and a limitation of Brussels's power, but their individual policies toward Russia and their visions of EU institutions are different. For instance, Poland failed to gain support from Hungary in its eastern policy, e.g., toward Ukraine. A visible sign of these differences was Budapest's veto of a Ukraine-NATO summit.

According to the National Security Strategy of the Republic of Poland 2014, strengthening democratic aspirations in eastern neighbourhoods reinforces Poland's security: "In the neighbourhood of Poland, there is a risk of regional and local conflicts which could engage the country indirectly or directly. Moreover, Poland is not free from forms of political pressure which use military arguments" (20). Polish Foreign Policy Priorities 2012-2016 highlights the importance of Ukrainian-Polish relations: "Development of relations with Ukraine, our strategic partner, has special importance for Poland. Consistent support of EU aspirations of the people of Ukraine and deepening NATO-Ukraine relations is a Polish foreign policy priority" (Priorytety polskiej polityki 18). ${ }^{1}$ Polish Foreign Policy Strategy 2017-2021 aims to reinforce infrastructural connectivity between Baltic and central

\footnotetext{
${ }^{1}$ My translation.
} 
European countries, including those located between the Baltic, Adriatic, and Black seas, and to continue Polish-Lithuanian-Ukrainian military cooperation as part of a joint brigade (6). Furthermore, the National Security Strategy of the Republic of Poland 2020 explicitly states: "The most serious threat is the neo-imperial policy of the authorities of the Russian Federation, pursued also by means of military force" (6). That strategy includes a need to strengthen the capabilities of the NATO and the European Union to ensure the security of Poland and to develop co-operation in bilateral, regional, and global formats to strengthen Poland's position.

During the July 2016 NATO summit in Warsaw, it was decided to counteract Russia by strengthening the military presence of NATO members on NATO's eastern flank. By 2017, there were four NATO battalions in the region, stationed in Poland, Estonia, Latvia, and Lithuania on a rotational basis, and NATO's Ballistic Missile Defence had a base in Romania. As Richard Sokolsky states, "From the West's perspective, Russia is a revisionist, neo-imperialist, and expansionist power determined to overturn the post-Cold War European security order, destroy NATO's cohesion, and restore its sphere of influence throughout the former Soviet Union." Consequently, NATO and Russia are stuck in a classic security dilemma in which each side bears the expense of the other side's efforts to improve security.

CONTEMPorary Modification: From an InTERmarium IdEA to the Three SeAS INITIATIVE

The inaugural Three Seas (Baltic, Adriatic, Black) Initiative summit was held in Dubrovnik, Croatia, in August 2016, with participation of twelve central and eastern European countries (Austria, Bulgaria, Croatia, Czech Republic, Estonia, Hungary, Latvia, Lithuania, Poland, Romania, Slovakia, Slovenia). This region accounts for $28 \%$ of EU territory and $22 \%$ of its population, but only $10 \%$ of the EU's gross domestic product. Polish President Duda said that from the beginning of his term the project of deepening ties between the countries of the so-called "Three Seas" (Trójmorza in Polish) was a constant part of his agenda ("Remarks by President Trump and President Duda"). Implementation of this model of co-operation will use the full potential of the countries lying between the Baltic, Adriatic, and Black seas (Cienski).

The objective of the Three Seas Initiative is to strengthen trade, infrastructure, energy, and political co-operation in the area between the Adriatic, Baltic, and Black seas. The countries involved in Three Seas Initiative share the same objectives: economic growth, security, and a stronger and more cohesive Europe. To achieve these goals, co-operation is promoted for the development of infrastructure in the energy, transport, and 
digital sectors. The Three Seas Initiative is supported by the United States, China (in some respects), and recently, Germany (which currently participates in the summits as an observer).

To date, Three Seas Initiative (TSI) summits have been held four times at the presidential level. The TSI encompasses 48 projects, focusing on three fields: energy, digital development, and transportation. Poland hosted the second TSI summit in Warsaw on 6-7 July 2017, and the guests included the president of the United States, Donald Trump, who reaffirmed the United States' strong support for the initiative and its objectives.

Despite some scepticism and mistrust on the part of Germany at the beginning of the TSI, Germany joined the TSI as a country-partner. The German Foreign Minister, Heiko Maas, took part in the Bucharest TSI summit in 2018. The president of the EU Commission, Jean-Claude Juncker, Germany's president, Frank-Walter Steinmeier, and the U.S. Secretary of Energy, Rick Perry, attended the TSI summit in Slovenia in 2019. According to Juncker, the apparent reason for attending was "because this is not something being directed against the European Union but it is adding to our efforts to make sure that the interconnectivity in this part of Europe is developing in the right direction" (European Commission). As stated in the objectives of the Three Seas Initiative, "[f]rom the outset, the Three Seas was designed to complement rather than compete with the European Union. This is reflected in the close involvement of the European Commission in the initiative and its participation in all of the most recent summits" ("Three Seas Story").

The TSI is economically supported by the Three Seas Initiative Investment Fund. Poland and Romania were the first to contribute to the fund, with a total of more than $€ 500$ million. The U.S. Secretary of State, Mike Pompeo, has indicated that the United States has committed to investing up to $\$ 1$ billion toward Three Seas Initiative energy projects through the U.S. International Development Finance Corporation. At the second TSI summit in Warsaw, U.S. President Donald Trump declared that the USA would support the initiative and would be a trusted ally and partner. He also offered energy resources and military technology to the TSI states ("Remarks by President Trump and President Duda"). In October 2019, the U.S. Congress introduced a resolution to support of the TSI in its efforts to increase energy independence and infrastructure connectivity, noting that such work would strengthen national security in the United States and Europe. As PierreEmmanuel Thomann states, "For Poland and its allies in the TSI, the alliance with the U.S. is considered necessary to contain Russia and expand their room for manoeuvre in the EU" (38).

Despite the widely declared exclusively economic nature of the TSI, the initiative could also have geopolitical objectives. The expansion of energy infrastructure will open up new routes for alternative energy suppliers to 
CEE countries, reducing their energy dependence on Russia. An expanded energy infrastructure could potentially counterbalance China's interest in participating in regional infrastructure projects as part of its global Belt and Road Initiative (Zbińkowski). The TSI agenda correlates with the geopolitical interests of the U.S. in the light of competition with Russia and China, and links with American economic interests. For example, disagreements between Germany and central European and Baltic countries have crystallized over the Nord Stream II project. For central European and Baltic countries, it is important to reduce dependence on Russian energy monopoly, but the Nord Stream II project makes it difficult to do so.

Ukraine received an invitation to the first inaugural summit of the TSI in Dubrovnik in 2016 but did not send delegates. Ukraine was not invited to the TSI summit held in Warsaw in 2017 because of the clear definition of the TSI as an economic project that involved only EU member states. Ukraine was invited to the business forum of the TSI summit held in Bucharest in 2018; however, the Ukrainian representatives again did not arrive. At the same time, a Joint Declaration adopted in 2019 at the summit in Slovenia confirms that the TSI is open to partnership with the Western Balkans and the Eastern Partnership countries in the initiative ("Joint Declaration"). Ukraine should be interested in this Initiative, at the very least because it is connected with energy security in Europe and there exist possibilities to join some infrastructure projects.

\section{CONCLUSIONS}

The Intermarium concept is an integral part of Polish geopolitical thinking and reflects the Polish nation's historical past and its hopes to become a dominant power in the region. Jan Marek Chodakiewicz argues that U.S. strategy had to focus on the Intermarium, as the Intermarium forms "the regional pivot and gateway to both East and West" and is "the most stable part of the post-Soviet area (and most free and democratic)" (2). In Ukrainian political discourse, geopolitical concepts of Intermarium exist exclusively in the realm of security discourse, but for Polish political imaginary it constitutes a discourse of identity-Poland as a core of European politics in the region.

An interwar Intermarium project focused on geostrategic issues as part of a security policy to ensure Poland's survival, but the European geopolitical configuration is different today. There is no desire to build a central European entity independent of the EU and NATO. In today's Polish foreign policy thinking, the Intermarium idea has moved toward the Three Seas Initiative (TSI) - a project promoted according to geo-economic arguments 
that include the need to limit dependence on Russian energy and to reduce German economic and political hegemony in the EU.

The new TSI is an attempt to strengthen the influence of central European countries in the EU, and Poland hopes to lead this initiative. The project does not have a direct political character, but the unification of voices and interests of CEE countries will increase the impact of TSI countries on the EU. At the same time, there are some suspicions about the Polish role in the TSI: "Poland is, therefore, voluntarily playing the role of a geopolitical pivot point for the United States, which should strengthen Poland's weight in the EU, maintain as much as possible the influence of the U.S. on the European project, counter Russia, and rebalance Germany's power in the EU" (Thomann 38). Poland's aim to be the main engine forming the new alliance is perceived by other states as an attempt to revive the Polish Commonwealth in the new environment. In June 2017, the Czech Minister of Foreign Affairs stated: "For us, the idea of the Three Seas is unacceptable. This is the 20th-century power concept of Piłsudski" (Kokot).

The Intermarium project can be viewed as an ambitious and courageous endeavour, but for a twentieth-century approach it is rather unrealistic. Although the idea is attractive, the Baltic-Black Sea axis is too divided to act as a united alliance, and the Intermarium countries are too heterogeneous in terms of political and economic development. Neighbouring countries perceive Poland to be an expansionist state, and this factor makes the Polish initiative suspect.

Other obstacles to the realization of the Intermarium project include complex unresolved problems that exist between the countries in the region. For example, there are deep contradictions in the interpretation of the history in Ukraine and Poland (Kononczuk). The ambitions of individual states, particularly Poland, would be an additional obstacle to the formation of an Intermarium. Poland does not have sufficient potential to be accepted by all countries in central Europe as an appropriate regional power, and not all countries in central and eastern Europe perceive Poland as an equal partner.

The Russian-Ukrainian conflict is only one manifestation of ongoing systemic changes in Europe and in the international order. The joint efforts of CEE countries is needed to overcome the cross-border nature of challenges to regional security. CEE countries must avoid becoming merely a buffer zone between Russia and Western Europe. Such threats create a basis for mutual co-operation of the countries in this region.

The Russian-Ukrainian war has revealed the ineffectuality and weakness of the European Neighbourhood Policy. The reaction of the European Union to Russia's aggressive foreign policy has shown that the EU is not ready to embrace the new geopolitical realities in Europe and prefers to remain within its familiar framework. Russian political elites still prefer 
to see the former Soviet Union countries as buffer states under Russian influence. The perception of eastern Europe as a sphere of Russian "vital interests" presents eastern Europe as a domain of Russian responsibilities, invoking reasonable fear in neighbouring states. Russia's hostility has revealed vulnerabilities in Ukraine's security and also the weakness in NATO's eastern flank: "It has become clear that NATO members' security was guaranteed rather by faith in the strength of the completed agreements than by military capabilities" (Horbulin et al. 23).

CEE countries hope to counter Russian resurgence and try to maintain the engagement of the United States in European affairs. CEE countries will turn to regional political and military alliances as alternatives if U.S. engagement is not forthcoming. The Polish response to the Russian aggressions in Ukraine has been strong and militarized, based on Poland's historical experience and defensive perceptions of such threats; however, other Visegrad countries (Czech Republic, Slovakia, Hungary) seem to have little concern regarding Russian threats (Peterson and Lubecki). According to Polish Foreign Policy Strategy 2017-2021, "Poland will also seek to improve regional resilience to crisis situations by enhancing connectivity between Baltic and Central European countries, i.e., within the BalticAdriatic-Black Sea triangle" (10). The Visegrad Group and the Nordic-Baltic grouping, although loosely affiliated, are working to formalize military components. The Visegrad Battlegroup, led by Poland, is an example of such attempts. The joint military brigade between Poland, Lithuania, and Ukraine (LITPOLUKRBRIG) established in 2015 could become a prototype for a joint military unit.

In the past, a number of small states between the Baltic and Black seas have faced security dilemmas due to their location between Europe's continental power centres. International security organizations and the United Nations have not been effective in solving these security crises in eastern Europe. The gradual reorientation of U.S. foreign policy toward other global regions has reinforced this trend. Consequently, countries across the region are looking for alternative mechanisms to strengthen their security, and projects such as the Intermarium, the Three Seas Initiative, or some other form of co-operation could be an answer to such insecurities in the future. However, the crucial question remains-is it possible to construct some "common" identity in this region? Based on diversity and contradictive nature of countries between Baltic and Black seas, I am skeptical. But, at the same time, the political needs in the changing international environment push national elites in this area to look for an appropriate format of cooperation. 
Works Cited

Address by President of the Russian Federation. President of Russia, 18 Mar. 2014, http://en.kremlin.ru/events/president/news/20603. Accessed 4 July 2019.

Balcer, Adam. "Międzymorze-Between Wishful Thinking and Realpolitik." Aspen Review: Central Europe, no. 3, 2016. https://www.aspen.review/article/2017/miedzymorze-between-wishfulthinking-and-realpolitik/. Accessed 12 June 2019.

Bieńczyk-Missala, Agnieszka. "Poland's Foreign and Security Policy: Main Directions." UNISCI Journal, no. 40, Jan. 2016, pp. 101-117. DOI: 10.5209/rev_RUNI.2016.n40.51808

Buzan, Barry, and Ole Waever. Regions and Powers: The Structure of International Security. Cambridge UP, 2003.

Chodakiewicz, Marek Jan. Intermarium: The Land between the Black and Baltic Seas. Transaction Publishers, 2012.

Cienski, Jan. "The World According to Duda." POLITICO, 19 Aug. 2015, https://www.politico.eu/article/duda-tusk-poland-foreign-policy-germanynato/. Accessed 3 Oct. 2018.

Dmowski, Roman. Niemcy, Rosja i kwestia polska. Instytut Wydawniczy Pax, 1991.

Dudek, Adriana. "Poland and Russia at the Turn of XXI Century. Between a Liberal Illusion and Imperial Realism." Revista UNISCI / UNISCI Journal, no. 40, 2016, pp. 77-99, https://www.redalyc.org/pdf/767/76743646006.pdf. Accessed 14 May 2021.

European Commission. "Discours du Président Jean-Claude Juncker au sommet de l'Initiative des Trois Mers." European Commission, 18 Sept. 2018, http://europa.eu/rapid/press-release_SPEECH-18-5825_fr.htm . Accessed 12 June 2019.

Fond "Demokratychni initsiatyvy" im. Il'ka Kucheriva. "Ievropeis'ka intehratsiia u vymiri hromads'koi dumky." Fond "Demokratychni initsiatyvy" im. Il'ka Kucheriva, 28 Sept. 2018, https://dif.org.ua/article/evropeyska-integratsiya-uvimiri-gromadskoi-dumki. Accessed 12 Jan. 2019

Gajowniczek, Tomasz. "Rosja a 'Międzymorze' w polskiej myśli politycznej XX wieku. Wybrane zagadnienia." Sprawy Wschodnie, no. 1, 2004, pp. 67-78.

Horbulin, Volodymyr, et al. Donbas and Crimea: Return at What Price? National Institute for Strategic Studies, 2016.

Ištok, Robert, et al. "The Intermarium as a Polish Geopolitical Concept in History and in the Present." Geopolitics, 6 Dec. 2018, pp. 314-41. DOI: 10.1080/14650045.2018.1551206

Jervis, Robert. "Cooperation under the Security Dilemma." World Politics, vol. 30, no. 2, Jan. 1978, pp. 167-214.

Kokot, Michal. "Wyłom w Trójmorzu. Czesi nie chcą być częścią antyniemieckiego paktu." Wyborcza, 19 June 2017, https://wyborcza.pl/7,75399,21976040,wylom-w-trojmorzu-czesi-nie-chcabyc-czescia-antyniemieckiego.html?disableRedirects=true. Accessed 9 Sept. 2019. 
Kononczuk, Wojciech. "The Paradoxes of Polish-Ukrainian Relations." Wilson Center, 23 May 2018, https://www.wilsoncenter.org/blog-post/the-paradoxes-polishukrainian-relations. Accessed 9 Sept. 2019.

Kyiv International Institute of Sociology. "Social and Political Attitudes of the Residents of Ukraine: April 2018." KIIS, 7 May 2018, http://www.kiis.com.ua/?lang=eng\&cat=reports\&id=764\&y=2018\&page=6.

Accessed 10 Jan. 2019

Lada, Agnieszka. Poland in Europe-Regional Leader or Outlier? Poland's European Policy in View of the Changes on the Continent. ISP, 2017.

Laruelle, Marlene. The "Russian World": Russia's Soft Power and Geopolitical Imagination. The Center on Global Interests, 2015.

Laruelle, Marlene, and Ellen Rivera. "Imagined Geographies of Central and Eastern Europe: The Concept of Intermarium.” IERES Occasional Papers, March 2019, https://www.ifri.org/sites/default/files/atoms/files/laruelle-riveraieres_papers_march_2019_1.pdf. Accessed 22 May 2020.

Makarychev, Andrey. "Regionalism and Identities in the Common Neighbourhood: European and Russian Discourses." CEURUS EU-Russia Papers, no. 10, 2013, http://ceurus.ut.ee/wp-content/uploads/2011/06/MakarychevEU-Russiapaper-10.pdf. Accessed 14 May 2021.

Maksak, Hennadiy, et al., editors. Ukrainian Prism: Foreign Policy 2016. Analytical Study. Foreign Policy Council "Ukrainian Prism," Friedrich Ebert Foundation, Office in Ukraine, 2017, https://library.fes.de/pdffiles/bueros/ukraine/13244.pdf. Accessed 14 May 2021.

Maszkiewicz, Mariusz. Między bezpieczeństwem a tożsamościq Rosyjskie, ukraińskie i białoruskie interpretacje idei i koncepcji w polskiej polityce wschodniej (19902010). Kolegium Europy Wschodniej im. Jana Nowaka-Jeziorańskiego, 2013.

Moczulski, L. Geopolityka. Potega w czasie i przestrzeni. Bellona, 2000.

National Security Strategy of the Republic of Poland, 2014, https://www.bbn.gov.pl/ftp/dok/NSS_RP.pdf. Accessed 12 Dec. 2016.

National Security Strategy of the Republic of Poland, 2020, https://www.bbn.gov.pl/ftp/dokumenty/National_Security_Strategy_of the_R epublic_of_Poland_2020.pdf. Accessed 3 Oct. 2020.

"Pro rishennia Rady natsional'noi bezpeky i oborony Ukrainy vid 6 travnia 2015 roku 'Pro stratehiiu natsional'noi bezpeky Ukrainy.'” Verkhovna Rada Ukrainy, 26 May 2015, http://zakon2.rada.gov.ua/laws/show/287/2015. Accessed 12 Dec. 2016.

Olbrycht, Marcin. Międzymorze-rozważania geopolityczne. Zeszyt szkoleniowy Młodzieży Wszechpolskiej. 2002.

Olszański, Tadeusz (J. Łukaszów). "Międzymorze-czym jest, czym może być?" Międzymorze, no. 2, 1998, pp. 37-43.

O'Tuathail, Gearóid. Critical Geopolitics: The Politics of Writing Global Space. Minnesota UP, 1996.

Parakhons'kyi, Borys, and Halyna Iavors'ka. Aktual'ni vyklyky ta zahrozy rehional'nii bezpetsi: vysnovky dlia Ukrainy. NISD, 2014.

Peterson, James, and Jacek Lubecki. Defense Policies of East-Central European Countries after 1989: Creating Stability in a Time of Uncertainty. Manchester UP, 2019. 
Polegkyi, Oleksii. "Regional Cooperation in Ukrainian and Polish Security Discourse." Baltic-Black Sea Regionalisms: Patchworks and Networks at Europe's Eastern Margins, edited by Olga Bogdanova and Andrey Makarychev, Springer, 2020, pp. 169-86.

Polish Foreign Policy Strategy 2017-2021. Gov.pl: Website of the Republic of Poland, 2017, $\quad$ https://www.gov.pl/attachment/869184c0-bd6f-4a20-b8afa5c8190350a1. Accessed 3 Oct. 2018.

Polish Ministry of Foreign Affairs. "Minister Witold Waszczykowski on Priorities of Polish Diplomacy." Polish Ministry of Foreign Affairs, 29 Jan. 2016, https://www.msz.gov.pl/resource/601901dd-1db8-4a64-ba4a9c80f2d5811b:JCR. Accessed 12 Jan. 2019.

Popescu, Nicu, and Andrew Wilson. The Limits of Enlargement-Lite: European and Russian Power in the Troubled Neighbourhood. European Council on Foreign Relations, June 2009, https://ecfr.eu/archive/page/-/ECFR14 The Limits of EnlargementLite._European_and_Russian_Power_in_the_Troubled_Neighbourhood.pdf.

Accessed 14 May 2021.

Potulski, Jakub. "Polish Geopolitical Visions. Poland As Intermarium." Territories As Identities in Central, Eastern and Southeastern Europe, edited by V. Mihaylov, Instytut Geopolityki, 2014, pp. 175-89.

Priorytety polskiej polityki zagranicznej 2012-2016. National Security Bureau, March 2012, https://www.bbn.gov.pl/download/1/9620/prpol.pdf. Accessed 3 Oct. 2016.

"Remarks by President Trump and President Duda of the Republic of Poland in Joint Press Conference." The White House, 18 Sept. 2018, https://trumpwhitehouse.archives.gov/briefings-statements/remarkspresident-trump-president-duda-republic-poland-joint-press-conference/. Accessed 5 July 2020.

Sokolsky, Richard. "Not Quiet on NATO's Eastern Front." Carnegie Endowment for International Peace, 29 June 2016, http://carnegieendowment.org/2016/06/29/not-quiet-on-nato-seasternfront-pub-63984. Accessed 14 May 2021.

Sotsiolohichna hrupa "Reitynh." "Portrety rehioniv': Pidsumky. Zvedeni dani, porivnial'nyi analiz mizh oblastiamy." Sotsiolohichna hrupa "Reitynh," 26 Dec. 2018, http://ratinggroup.ua/research/ukraine/portrety regionov itogi svodnye dan nye sravnitelnyy analiz mezhdu oblastyami.html. Accessed 17 Sept. 2019.

Starzyk, Adam, and Natalia Tomaszewska. "Conception of Intermarium in Polish Foreign Policy in XXI Century." Torun International Studies, vol. 1, no. 10, 2017, pp. 15-28. DOI: 10.12775/TSM.2017.002

Szczepański, Tomasz. "Międzymorze-zapomniana idea niezależności narodowej i stabilizacji regionalnej.” Obywatel, no. 3 (29), 2006.

Szelachowska, Ksenia. "The Revival of Intermarium-Poland Can Talk the Talk but Can It Walk the Walk?" Stratfor, 14 Jan. 2016, https://www.stratfor.com/thehub/revival-intermarium-\%E2\%80\%93-poland-can-talk-talk-can-it-walkwalk. Accessed 14 May 2021.

Thomann, Pierre-Emmanuel. "The Three Seas Initiative, a New Project at the Heart of European and Global Geopolitical Rivalries." Yearbook of the Institute of EastCentral Europe, vol. 17, no. 3, 2019, pp. 31-63. 
“Three Sears Story." Three Seas, https://3seas.eu/about/threeseasstory. Accessed 23 June 2021.

Tsygankov, Andrei. "Vladimir Putin's Vision of Russia As a Normal Great Power." Post-Soviet Affairs, vol. 21, no. 2, 2005, pp. 132-58. DOI: 10.2747/1060586X.21.2.132

Umland, Andreas. "How to Fill Ukraine's Security Vacuum." Carnegie Europe, 12 April 2016, http://carnegieeurope.eu/strategiceurope/?fa=63300. Accessed 14 May 2021.

Wagrowska, Maria. "Visegrad Security Policy: How to Consolidate Its Own Identity." International Issues and Slovak Foreign Policy Affairs, vol. 18, no. 4, 2009, pp. 3143.

Waltz, Kenneth. Realism and International Politics. Routledge, 2008.

White, Stephen, and Valentina Feklyunina. Identities and Foreign Policies in Russia, Ukraine and Belarus. Palgrave Macmillan, 2014.

Wolczuk, Kataryna. "Ukraine and Its Relations with the EU in the Context of the European Neighbourhood Policy." Ukraine: Quo Vadis?, edited by Sabine Fischer, Chaillot Paper, no. 108, 2008, pp. 87-117, https://op.europa.eu/en/publicationdetail/-/publication/33c0e093-f117-4cb4-bff5-22c024875573/languageen/format-PDF/source-122129310. Accessed 14 May 2021.

Zbińkowski, Grzegorz. "The Three Seas Initiative and Its Economic and Geopolitical Effect on the European Union and Central and Eastern Europe." Comparative Economic Research, vol. 22, no. 2, 2019, pp. 105-19. DOI: 10.2478/cer-20190015 